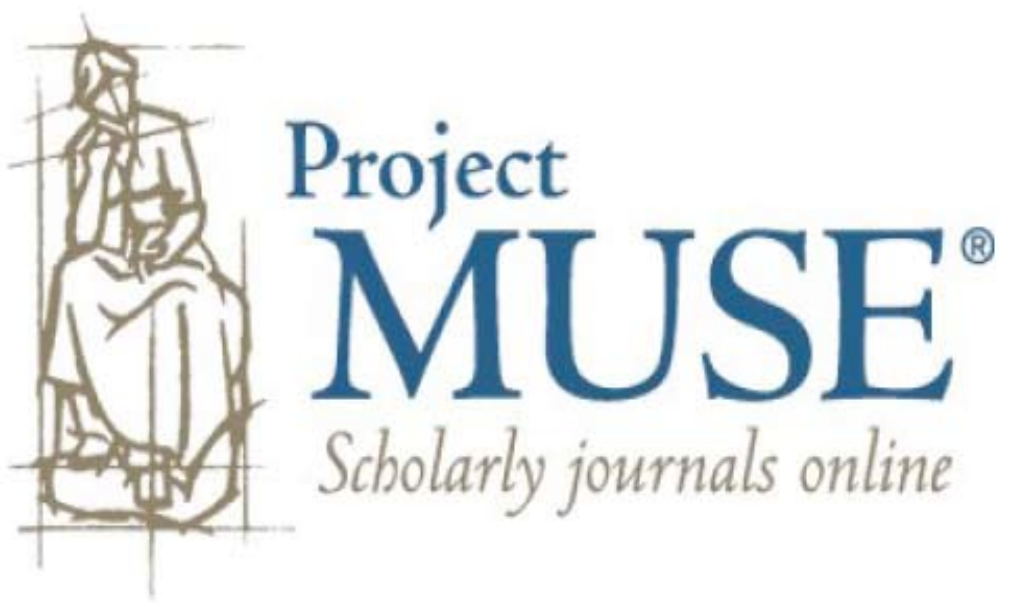




\title{
Precision Targets: GPS and the Militarization of U.S. Consumer Identity
}

\author{
Caren Kaplan
}

Here I believe one's point of reference should not be to the great model of language (langue) and signs, but to that of war and battle. The history which bears and determines us has the form of a war rather than that of a language: relations of power, not relations of meaning.

-Michel Foucault, "Truth and Power"1

$\mathrm{F}$ or most people in the United States, war is almost always elsewhere. Since the Civil War, declared wars have been engaged on terrains at a distance from the continental space of the nation. Until the attacks on the World Trade towers and the Pentagon in September 2001, many people in the United States perceived war to be conflicts between the standing armies of nation-states conducted at least a border-if not oceans and continents-away. Even the attacks of September 11 were localized in such a way as to feel as remote as they were immediate-watching cable news from elsewhere in the country, most U.S. residents were brought close to scenes of destruction and death by the media rather than by direct experience. Thus, in the United States, we could be said to be "consumers" of war, since our gaze is almost always fixed on representations of war that come from places perceived to be remote from the heartland.

Digital communications and transnational corporate practices are transforming the modes, locations, and perceptions of nationalized identities as well as the operations of contemporary warfare. Certainly, war is consumed worldwide by global, as well as national, audiences. Indeed, if the conflicts of the present age cannot be described as between nation-states but as between the extra- or transnational symbols of political, religious, and cultural philosophies or ideologies, drawing on national identity becomes a more challenging task. Yet, conditions specific to the United States need to be explored in relation to the network of discourses, subjects, and practices that make up our nation and its government. The United States still signifies a coherent identity, if only as the enemy or perpetrator of attacks against people outside its national borders or as the defender of borders that are perceived by many of its residents as too porous and insecure. Situating the cultural, political, and economic workings 
of the United States within transnational conditions aids our understanding of the ways in which national identity operates as a powerful enhancement to contemporary globalization. The issue is not the difference between national and international subjects of study but the mystification of the national such that its identifications with global capital disappear from view, leaving behind patriotic articulations of security, prosperity, and freedom.

When U.S. President Dwight Eisenhower and his speechwriter Malcolm Moos coined the term "military-industrial complex" in 1961, they described a moment poised between the aftermath of the world wars and the advent of the conflicts to come in which the U.S.-based armaments industries could combine their influence with those in the military and the government, who would come to gain from such an alliance. Eisenhower argued that this kind of war corporatism could tip the hallowed liberal balance between defense and social programs, leading to a war economy without end. Over the last forty years, the hybrid form of governmentality that Eisenhower delineated in his speech materialized as Congress, industry, and the military created a culture of cooperation that overcame any internal tensions to produce a normalization of what could be construed as conflict of interest, or even cronyism. As the work of James Der Derian, Tim Lenoir, Jennifer Terry, and others demonstrates so powerfully, for people in the United States war is not at all elsewhere but is, in fact, deeply imbricated in everyday life as a "military-industrial-mediaentertainment network."

Who becomes a militarized subject through this network in the United States today? Two primary ways in which militarization operates in U.S. contemporary culture are the pervasive use of Geographic Information Systems (GIS), the primary model of data collection, sorting, and storage in use for over thirty years, and the practice of so-called target marketing, a geographically based form of classifying neighborhoods through subsets of demographic information. The same year that Eisenhower critiqued the military-industrial complex, scientist Jonathan Robbin founded General Analytics Corporation (GAC - the forerunner of Claritas, Inc.) to explore the industry potential of a new science-geodemography, the use of the computer to identify and map subsets of the U.S. population by zip code and neighborhood. Throughout the 1960s and into the 1970s, GAC/Claritas linked geography to demography by drawing on the statistics and classification system used in the biological sciences to categorize plants and animals by species and by fine-tuning the zoning capacities of U.S. Postal Service zip codes. By the 1970s, Claritas was applying multivariate regression analysis to census and marketing survey data and "target marketing" could be said to be in full swing. ${ }^{3}$ 
Geodemography and target marketing could come about, however, only as an outgrowth of GIS. The power of GIS lies in its ability to link information and inquiries of various kinds to location. The flexibility of its analytical capacities can be attributed to the ways in which the system combines layers of information, including visual material, to answer complex questions in increasingly precise registers. As John Pickles has argued, GIS "contributes to a (re)placing of the 'visual' and the 'spatial' at the center of social life through its role as an element in the restructuring of global, regional, and local geographies, the assertion of new disciplinary codes and practices, and the constitution of new images of earth and society." ${ }^{4}$ It is difficult to imagine the Web-based Internet with all of its graphic interfaces without the cultural shift engendered by GIS. Indeed, it could be said that the centrality of geographical images in information sciences helped to create the visual logics of contemporary U.S. subjectivity.

The development of GIS exemplifies the era of the military-industrial complex. Its emergence required computer research, geo-mapping, photography, and satellite programs - a process that involved academic, government, military, and commercial participation. The science behind GIS is not limited by nationality. Most histories point to the development of "Canadian GIS" (CGIS) in 1967, the system invented by that country's Department of Energy, Mines, and Resources to inventory land use and geographical information, as the first fully realized "system." The power and resources of the transnational technoscience that the United States and the U.S.S.R. "raced" to secure were fully available to the U.S. military and research universities during the cold war. As the United States rushed to militarize space and extend the range of weapons that could be used for deterrence or for waging attacks on competing superpowers, computer science and satellite programs burgeoned. The geographic identification, sorting, and surveillance offered by GIS produced new commercial, military, academic, and governmental needs. Combined with the remote sensing capacities of new satellite systems that could generate continuous images of the earth's surface, GIS provided an affirmation of the "whole earth" ethos that was coming to characterize the cultural zeitgeist in the United States during the 1960s and 1970s while offering fresh possibilities for security and surveillance as the cold war alliances shifted and reconfigured under the pressures of new conditions and crises. ${ }^{6}$

I am particularly interested in the temporal and discursive overlap of these two technologies, GIS and geodemography, with a third: the global positioning system (GPS). All three emerge in the postcolonial era of globalization with all of its attendant tensions and negotiations between national and transna- 
tional culture. GPS originated as a military technology-a system of satellites launched by the U.S. Department of Defense in the early $1970 s^{7}$ - that offered precise ground locations for both defensive and offensive purposes. ${ }^{8}$ The offensive purposes most famously enabled by GPS were the navigation of the weapons systems during the first Persian Gulf war in 1990-91. Since that time, and in connection with a complicated process of partial declassification and cooperative ventures between civilian, governmental, military, and commercial interests, GPS has become a ubiquitous consumer technology available in cars, watches, and PDAs. GPS has become integrated into the agriculture and transportation industries, law enforcement, and innumerable other commercial, municipal, and federal applications (it crops up regularly in discussions of border security).

In this article, I am inquiring into the conditions that produce U.S. militarized consumer and citizen subjects in relation to technologies that link geography, demography, remote sensing, and contemporary identity politics (including geopolitics). These subjects can be understood to be the "targets" of two seemingly distinct contexts and practices: the target of a weapon and the target of a marketing campaign. ${ }^{9}$ In both cases, something or somebody has to be identified, coordinates have to be determined with available technologies, and the target has to be clearly marked or recognized in time and space. GIS provides the model for databases as well as the representational logic for both warfare and marketing, while GPS offers enhanced precision in locating such targets through accurate positioning. Geographically based location technologies that draw on discourses of precision make possible the subjects of both consumption and war.

\section{"Where Am I? Ask a Satellite" 10}

The technology is already here. Drivers using the Global Positioning System (GPS) have an option to jump in their cars, plug in area maps, and know exactly where they are. Pilots, charting their own courses, can savor free flight, saving time and fuel as they go, and sailors can navigate harbors in high-tech mode. Up-to-date hikers are already augmenting the compasses in their gear with transistor-size GPS receivers, and truck drivers are both tracking and being tracked. It will not be long before universal GPS coordinates serve as postal zip codes. Business cards will list not only telephone and fax numbers and e-mail addresses but will give precise latitude and longitude coordinates for our home and business addresses.

-L. Casey Larijani, GPS for Everyone $e^{11}$

Commercial and civilian GPS publications tend to characterize GPS as an advance in human society on the order of the discovery of fire or the antibacte- 
rial properties of soap. An introductory GPS textbook from 1996 tells us that GPS is the "ultimate achievement of humankind's urge to know where [one is], at extraordinarily high levels of precision." 12 At the heart of this overheated assertion is the belief that human beings are urgently concerned with where they are and where they are going. Most important, technological assistance in the direction and interpretation of these processes is required. From "the clay tablets of the Mesopotamians some 5,000 years ago" to the GPS-enhanced watch or cell phone of the corporate executive in contemporary U.S. society, the truism of the desire to know where you are is presented as absolute and unquestioned. ${ }^{13}$ Regardless of political perspective, U.S. discourse on GPS throughout the 1990s and into the next century assumes that "maps hold some primal attraction to the human animal." 14 The "lure" of maps, presented as timeless and cross-cultural, is presented as a foundational attitude of civil society-access to mapping (especially technologically enhanced mapping) is a hallmark of democracy. From the end of the first Persian Gulf war and throughout the 1990s, as GPS increasingly became part of the popular imaginary of location and navigation in the United States, enthusiastic endorsements of "GPS for Everyone" offered precise positioning for the masses. ${ }^{15}$ As a 1994 article in the Wall Street Journal put it, GPS is "An Answer to the Age-Old Cry: Where on Earth Am I?" 16 A piece in Rolling Stone in 1992 trumpeted, "Lost in America-Not!"17

The proliferation of ads, press releases, and media spots (such as coverage in tabloid TV and print media on celebrity use of GPS) throughout the 1990s and into the next century focused on location-where you are-but linked closely to that designation was almost always something existential: where you are reveals who you are. For example, a 1995 article on in-car navigation systems in Popular Science boasted: "Real Men Don't Ask Directions." ${ }^{18}$ A software review in 1993 advised: "Find Yourself with GPS MapKit SV."19 For North Americans, the marketing of this novel technology emphasized personal empowerment and self-knowledge linked to speed and precision (save time, increase efficiency, avoid getting lost). Buried in the promotional hype of the emerging technology was the kind of conventional paradox of hegemony with which middle-class consumers of digital electronics are now quite familiar in the new millennium: the digitalization of information about yourself that you provide voluntarily to enhance your "lifestyle" also brings you into networks of surveillance. Who you are, geographically, is a target—of marketers, governments, identity thieves, hackers, and so on. ${ }^{20}$

When civilians use commercial digitalized navigational assistance based on GPS, then, they are participating in the expansion of mapping into more 
extreme relational contexts, which has the effect of intensifying unequal social relations. The digital mingling of position and identity into target subjects underscores the martial and territorial aspect of mapping throughout the modern period. Maps are always subjective representations; their parameters and spatialized views reflect the needs and interests of those who intend to use them. While the history of maps stretches back into the earliest recorded representations, the rise of print culture, the spread of capitalism, and the desire to chart the mobile circulations of modern culture created a specific practice of mapping. ${ }^{21}$ New nation-states required maps of redrawn borders. Maps became indispensable to track armies in war. By the turn of the nineteenth century, the convergence of aerial perspectives made possible by aviation and the relatively new technology and art of photography intensified the visual logic of mapping to the degree that it became possible, and even an advantage, to conduct war from the air. ${ }^{22}$ Thus, the legacy of geography, war, and aerial perspective are writ large in GPS. When people turn to satellites to tell them where they are, they mobilize these histories. At the same time, these technologies of location situate consumers within the mythologies of individual empowerment and precision that advertisers employ to market the idea that one must always be locatable.

\section{The Ultimate Achievement: The Myth of Precision}

In order to release a bomb so that it will hit the target, the exact point in space must be determined.

-Albert L. Pardini, The Legendary Norden Bombsight ${ }^{23}$

Like many technologies in use in daily life, GPS was created as a result of military research and development. While its commercial and industrial applications bear little resemblance to practices of war, the ways in which GPS operates in daily life are extremely similar to its original purpose, targeting through precise positioning. ${ }^{24}$ Yet precision is a relative concept. Oceans have been navigated with a sextant and the naked eye, but the destined port of harbor does not have to be observed within terms that we would think of as "precise" today. The imaginary properties of precision adjust to the means available to achieve them. Thus, the powerful association of GPS with precision marks a nexus point in discourses of modern technoscience, especially those linked to aviation and remote sensing. The quest to pinpoint precisely the object of sight, as when aiming a weapon, emerges as a collaborative goal for the military-industrial complex only if the right tools are available to meet the dominant cultural, economic, and political imperatives. 
GPS exemplifies the belief in precision as a required element in armaments, especially in bombardment, and the militarization of space. According to military historians, the entire rationale for GPS development was linked to the demands of precision in missile guidance. Standard histories point to the checkered experience of aerial bombing raids during the world wars and after to demonstrate the importance of accurate targeting, especially for bombardments at night or in poor weather conditions. However, Donald MacKenzie argues that the desire for bombing precision is neither natural nor inevitable but the product of "a complex process of conflict and collaboration between a range of social actors including ambitious, energetic technologists, laboratories and corporations, and political and military leaders and the organizations they head." ${ }^{25}$ MacKenzie's research demonstrates that a technologically determinist discourse of accuracy or precision marks the attitudes of both the political Right and Left in debates about military technologies during the period between the two world wars. How precision came to dominate discourses of military strategy in the period before World War II through the Vietnam War and beyond to the first Persian Gulf war is a complicated tale of the competing claims on resources between the branches of the U.S. armed forces as well as the growing power of what should really be termed the governmental-military-industrial complex. ${ }^{26}$ Above all, the mystique of precision became the underlying rationale for the founding of an air force separate from the navy (which had its own flight craft and pilots) and for the organizing of U.S. national defense and offensive warfare on the principles of airpower.

The rise of airpower as a military strategy is linked to the belief, passionately argued in the aftermath of WWI's previously unimaginable number of civilian as well as military casualties, that precision bombing would be a more humane practice than previous strategies of ground wars. Intrinsic to the argument for aerial bombardment are the key European Enlightenment precepts of distance, precision, and the truth-value of sight. Each of these concepts itself requires an underlying belief in the mastery of technology and the superiority of information systems that privilege vision. Nothing brought these disparate discourses and ideologies together more effectively than the development of enhanced bombsights in WWII. The ability to target selected sites on the ground from a machine traveling at rapid speeds through uncertain weather at heights great enough to remain safe from enemy detection and attack was not easy to achieve. The U.S. military itself was divided on the subject of airpower and the necessity of a separate air force branch. ${ }^{27}$ Moreover, given the technological constraints, it was not clear that the moral high ground that precision bombing seemed to offer was achievable. Navigational and computational errors, inaccurate intel- 
ligence, weather interference, and human and technological failures often sent bombs awry, killing innocent civilians while destroying nonmilitary sites and structures. Nevertheless, the impression prevailed that U.S. precision bombing was far superior to its obverse strategy: tactical or saturation bombing, a technique that focused on destroying the morale of the civilian population in enemy territory through wide-scale devastation and terror. ${ }^{28}$

Aerial bombardment during WWI had consisted of dropping armaments by hand with "no bombing sights, no aiming points, and no true bombs." ${ }^{29} \mathrm{As}$ the world geared up for the next war, entire industries were pressed into the quest for high-tech solutions to the perceived need for precision-both to better the record of aerial bombardment and to protect the lives of the airmen. With the new bombsights developed for WWII, popular belief held that a bombardier's precision was increased such that he could "drop a bomb into a pickle barrel." 30 While this claim to precision was often contradicted by evidence, the bombardier became a heroic, even iconic, figure in popular perception. ${ }^{31}$ As Conrad Crane argues, accurate daylight bombing, with its precision mystique, called upon "traditional," favored American characteristics such as marksmanship, fair play, and other "frontier" stereotypes, adding to its strategic appeal to planners and the public alike. ${ }^{32}$ The precise aim of the bombardier (in truth, more the result of skilled mathematical calculation and new technologies than the classic "line of sight" attributed to great marksmen) became legendary. The development of the Norden and Sperry bombsights, along with the engineering of the B-17 long-range airplane (known as the "Flying Fortress"), brought daylight precision bombing into the policy and strategy of modern warfare as an integral component of airpower.

The bombsights developed for use in WWII were designed to address the problem of hitting a stationary target from a moving vehicle, the airplane. As Albert L. Pardini, one of the most devoted chroniclers of the Norden bombsight, explained the process, "a falling bomb, in order to hit the target, must be released at the correct distance back from the target so that it will not fall short or over." ${ }^{33}$ Factors such as gravity, true airspeed, air resistance, and wind had to be accounted for as well. Since the Norden bombsight used gyroscopes to hold the optical system in place during the movements of the plane through the air, it was viewed as a huge advance over the aerial surveillance and bombardment used in WWI. The Norden bombsight and its counterparts transformed problems of time and space into principles of geometry-offering the latest science and technology to the bombardier, who was responsible not only for delivering the payload of armaments as accurately as possible but for getting the entire crew back safely by reducing costly repetitions and extra runs. It 
was highly valued by the air crews who used it and became the subject of its own mythologized reputation (complete with fan clubs, exhibitions, Web sites, etc.)..$^{34}$

The use of the Norden bombsight during WWII has been trumpeted as the technology that made airpower possible. Yet, the United States developed a doctrine of airpower, based on precision and the capacity of long-range bombers to reach their targets, that was not, in fact, able to be sustained under actual conditions of war. As Crane relates, elements such as weather, inadequate training, defensive fire, and camouflage resulted in only 14 percent of the bombs dropped by the Eighth Air Force during the first half of 1943 to hit within 1,000 feet of their targets (rather than the 90 percent advertised by the top brass at the beginning of the war). ${ }^{35}$ The predicted precision of bombing raids, as Murray points out, was based on "unrealistic" situations: "on bombing ranges in the south-western United States, in conditions of perfect visibility, with bombers dropping on an individual basis and with no hostile anti-aircraft or enemy fighters." 36 Thousands of U.S. and allied flight crews lost their lives in pursuit of daylight targets when they came under sustained defensive fire in the theater of war.

Despite these significant problems in execution, the airpower mystique of precision presented a cleaner, neater image than the wholesale, destructive blasting of terror bombing or cannon bombardment. The airmen who died either were incinerated or decimated in the air on impact or in the ruins of their aircraft if they hit the ground - arguably less of a cumulative visual calamity than the thousands of corpses moldering in the trenches of World War I. If, as Sven Lindqvist argues, Europe and the United States had learned from their colonial experiences that terror was the best way to devastate morale and crush opposition, the emergence of the doctrine of airpower and precision bombing proved to be the only acceptable rationale for the kind of large-scale attacks necessitated by wars between industrial powers in the modern period. ${ }^{37}$ Thus, the doctrine of precision, while pervasive, could not overlay completely the fact that morale or terror bombing was an accepted practice of the U.S. military and its allies. The firebombings of Dresden and Tokyo, therefore, were but dress rehearsals for the decision to drop atomic bombs on Nagasaki and Hiroshima. While the use of the atomic bomb appeared to shift the logic from precision to mass, total terror and destruction, it is with the development of GIS and satellite-guided missile systems that characterize later wars that airpower and the mystique of precision return with a vengeance. 


\section{The Precision of "Space Power" and the First Persian Gulf War}

One of the major advantages that planners like Schwarzkopf possessed was excellent intelligence assets. The environment of the desert campaign lent itself to the acquisition of accurate information about the enemy. In space, reconnaissance satellites like the KH-11 and the lacrosse radar-imaging satellite provided untouchable (by Iraqi forces) coverage of the battlespace. Other satellites carried the critical communication channels and equally important were those satellites that allowed the global positioning system (GPS) to work. GPS allowed unprecedented levels of accuracy concerning battlefield navigation that was so vital in maneuver warfare.

\section{-Alastair Finlan, The Gulf War 199138}

Precision returns as a popular discourse in military-industrial society when positioning technologies made possible by the satellite systems that were launched in the 1970s and '80s offered new standards of accuracy. ${ }^{39}$ Most histories of the Persian Gulf War make the point that this was the first war to make extensive use of satellite technology. Not even fully operational when the war began in 1990, GPS quickly took pride of place in the pantheon of satellite-assisted technologies that the U.S. military and its allies used in the conflict. Combining multispectral imagery from US LANDSAT remote sensing and GPS, commanders had access to detailed maps that could be updated quickly and accurately. Approximately 4,500 GPS receivers were used in the war, winning over troops on the ground and pilots in the air. ${ }^{40}$ Shifting the scale of airpower to "space power," GPS and other satellite systems aided both air and ground forces, enhancing conventional aerial surveillance to offer a network of image-based mapping and navigation.

The twenty-four NAVSTAR GPS satellites and their military and governmental counterparts were not the only orbital technologies that affected the perception and outcome of the war. The conflict in the Persian Gulf in the early 1990s has been characterized as the first televisual war (in contrast to the film-based information broadcast during the war in Vietnam). ${ }^{41}$ The speed, immediacy, and accuracy of the real-time images broadcast by twenty-four-hour cable news services such as CNN depended on satellite telecommunications to an unprecedented degree. If during WWII newsreels reached movie theater audiences no less than a month after the occurrence of events depicted, that time lag had been reduced to approximately twenty-four to forty-eight hours between filming on-site and broadcast by TV during the Vietnam war. ${ }^{42}$ During the first Persian Gulf war, the seemingly real-time television coverage of Patriot missiles and Scud attacks generated what Robert Stam has called the "pleasures of war spectatorship"; ${ }^{43}$ CNN's five telecommunications satellites fed simulated 
"live" accounts twenty-four hours a day, offering greater identification with the military apparatus for many of the viewers glued to their sets during the relatively short-lived conflict.

The truth effect of digital immediacy and the mystique of satellite-aided precision presented a view of the war that built upon the realist documentary tradition. ${ }^{44}$ Although most of the visual material that was transmitted was heavily censored by the Pentagon, it was presented as live and unmediated. Many commentators point to the contrast between the Vietnam War, where reporters were able to roam mostly at will (which brought the complexity and atrocities of the conflict into the living rooms of the general U.S. public via TV), and the managed "pool" approach mandated by the Pentagon during the first Persian Gulf war (establishing the approach for succeeding wars). The media image of the conflict in the Gulf, as Stig Nohrstedt explains, was "ruled by restrictions on journalists' freedom to visit front areas, troops, damaged buildings, and so on without military escorts." ${ }^{\prime 5}$ Reporters, desperate for footage and for any kind of story line, relied on whatever technology could provide. Thus, the "you are there" effect of reporters describing tracer fire from their Baghdad hotel room windows was reinforced by the seeming speed of the transmissions. As many commentators have argued over the years since the war, the media, in general, played technological handmaiden to the U.S. military in its effort to manage the representation of the conflict. As Douglas Kellner relates in his history of the television coverage of the war, "the initial strategy of the war managers was to present an image of the war that was clean, precise, and effective." ${ }^{46}$ Since the military was engaged in a public relations campaign as well as a military engagement, the mystique of precision bombing helped to allay concerns about civilian casualties and damage to nonmilitary and religiously significant sites. ${ }^{47}$ The airpower doctrine of precision bombing, here aided by GPS and other GIS-related mapping technologies, combined with the seemingly instantaneous media coverage that was enabled by telecommunications satellites to reassure the U.S. population that the heroic project of saving Kuwait from Iraqi invaders was not going to be messy, wasteful in terms of lives and money, or boring. Thus, in the early 1990s, the governmental-industrial-military-complex linked once and for all with the media-entertainment complex-forming new subjects of a militarized visual culture. ${ }^{48}$

If the Norden bombsight captured the imagination of the military and public alike during WWII to assuage concerns about the morality of bombing, engendering discourses of precision and aerial mastery, GPS played a significant role in the public relations war as it was spun in the "military-industrialmedia-entertainment network" of the Persian Gulf war. As Daniel Hallin has 
put it, "overwhelmingly the dominant images of Persian Gulf coverage were the images of triumphant technology." ${ }^{4}$ Since the media were barred from battlefield coverage, they resorted to iconographic images that played to the nationalist sentiments of TV watchers at home and kept them tuning in: "the Patriot streaking up to hit a Scud in the night sky; the cruise missiles arching gracefully toward their targets; the jet fighters landing at sunrise or sunset (a favorite TV visual) with soldiers watching and giving the thumbs-up sign; and most characteristically, the smart bomb video." 50

The visual elements of the "smart" weapons entranced many Persian Gulf war spectators. An editorial published in the Nation during the war in February 1991 relates the example of liberal viewers who enthused, "we hate the war . . . but we are into the planes." ${ }^{1} \mathrm{Or}$, as reporter Fred Kaplan recalled in the late 1990s, "seven years have passed since the last time the United States bombed Iraq, but one gripping image lingers_-video footage shot on Jan. 17, 1991, the first night of the air war, of a laser-guided bomb plunking straight down the chimney of an Iraqi Air Force building and blowing the place off the map." 52 These "gripping" images were produced by video cameras in the "smart" bombs that were designed to record the strike. In the absence of other visual records, the "smart bomb" footage took on a privileged percentage of the display of technological prowess for which the war is known. The "objective eye" of the smart bomb linked the values of realism, action, and precision that many spectators came to regard as a guilty or not-so-guilty pleasure-watching the U.S. blow stuff to bits in an urban or desert landscape that appeared to be devoid of human beings. The explosions were represented as precise strikes "through windows" or "down chimneys" of selected targets. Thus, the guiltless pleasure of viewership was as much due to the belief in the power of precision and the thrill of knowing that the armaments were moving through space and time at enormous speeds to strike a target with exceptional accuracy.

The overwhelming impression conveyed by the military-industrial-media-entertainment network was that the United States and its allies were undertaking precision attacks on military targets, thereby conducting war on a higher moral plane and avoiding unnecessary "collateral damage" and, not incidentally, offering good visual entertainment. ${ }^{53}$ However, as numerous commentators have pointed out in the years since the war, although most of the bombs dropped in Iraq (approximately 90 percent) were regular "gravity" or "dumb" bombs without laser or satellite guidance and while a high percentage of those bombs missed their targets (some estimates go as high as 70 percent), what most Americans probably remember about the war is the discourse of precision linked to the imagery produced by the so-called smart bombs. Yet, 
the precision-guided bombs were also likely to miss their marks. Weather, human error, poor intelligence, and any number of other problems plagued the laser- and GPS-guided missiles and bombs. And, despite the hype, more of the "smart" weapons in the first Gulf war were guided by laser systems than by GPS (which has gained proportionate majority in precision-guided weapons programs in subsequent wars). Significantly, the well-documented imprecision of the bombing campaign just never gained any traction, since the evidence runs so counter to the discourse of precision and technological mastery that dominated the airwaves during the conflict itself. The most notorious mishap occurred on February 13, 1991, when, based on intelligence identifying the site as a military hard target, a guided missile hit the Ameriya civil-defense shelter at 4:30 a.m., killing between 200 and 300 civilians. In a 402-page published report, Middle East Watch chronicled "needless deaths" during the war due to innumerable violations of the official U.S. military and allied policies, such as daytime bomb and missile attacks on targets in populated areas, lack of warning, strafing attacks on civilian vehicles on highways, attacks on Bedouin tents, and so on. The report concluded that approximately 3,000 civilian Iraqis died from direct attacks, while a "substantially larger" number died or suffered greatly from malnutrition, disease, and lack of medical care caused by "a combination of the U.N.-mandated embargo and the allies' destruction of Iraq's electrical system." ${ }^{4}$

"Space power" and the vast resources of the military-industrial-media-entertainment network generated discourses of precision that obscured information about civilian deaths or rendered them inconsequential. The representation of the war was less embodied than previous representations of wars, with U.S. military casualties going undercover or under the radar, as it were, as well. If the "witnessing" of the war came from the missiles themselves, the point of view was singular, unidirectional, and heavily censored in favor of orchestrated displays of precision. Thus, much of what took place on the ground during the war was never a matter of public record in the globalized televisual experience of the "real." In effect, in the coverage of the Persian Gulf war the U.S. public watched an extended commercial for GPS.

\section{Aftermath: Target Subjects of the Military-Industrial-Media- Entertainment Network}

While classical liberal political theory has understood social rights as opposed to market relations, by the late twentieth century and the early twenty-first consumer culture had become central to liberalism and neoliberalism, promoting endlessly the idea of choice 
as central to a liberated subject and enabling the hegemony of both capitalist democracy, American style, and the self-actualizing and identity-producing possibilities of consumption, American style.

\section{-Inderpal Grewal, Transnational America ${ }^{55}$}

The first Persian Gulf war was not anomalous. If it was the first war to be "driven" by satellite technologies, the logics of those weapons and communications systems built on the practices and problem-solving techniques of previous wars. The amplified opportunities for research, development, and profit making that marked the emergence of the military-industrial complex in the 1960s and its expanded transnational formation, the "military-industrial-media-entertainment network" at the close of the twentieth century, provided fertile ground for the discursive fields of "technoscience," that "world-building" set of alliances that Donna Haraway has identified as "military needs, academic research, commercial development, democracy, access to knowledge, standardization, globalization, and wealth. ${ }^{56}$ At the turn of the century, technoscience and its networks produce target subjects through discourses of precise scales and sites of identity. Yet even as these modes of identification promise greater flexibility and pleasure through the proliferation of "choices" among myriad specificities, they also militarize and thus habituate citizen/consumers to a continual state of war understood as virtual engagement. As Jordan Crandall argues, operational media such as GPS-enhanced devices and their ancillary discourses aim to "increase productivity, agility and awareness, yet they vastly increase the tracking capabilities of marketing and management regimes," thereby facilitating the integration of military, corporate, and leisure interests. ${ }^{57}$ Lured by "individually tailored enticements," the subjects of technoscience, dedicated to "choice" and to "democracy" as the twin bulwarks of the U.S. "lifestyle," become targets of the information systems they use to satisfy their desires. As Crandall writes, "tracked, the user becomes a target within the operational interfaces of the marketing worlds, into whose technologies state surveillance is outsourced." 58

Most people who search for driving directions on Web sites or who check out "Google Earth" and other services that offer free satellite photography of specific locations are largely unaware of the military infrastructure that supports such activities. Similarly, most people are not aware of their identification for target marketing through computer databases linked to the use of credit cards, supermarket cards, and driver's licenses. GIS is not a subject of informed discussion among most consumers in the United States even if they may be able to debate the virtues of a GPS-enabled automobile when faced with a 
choice of rental cars. Thus, as DeLanda and other theorists of militarization have pointed out, the ways in which military institutions, resources, and discourses structure facets of nonmilitary life are mystified in the energetic "forgetting" of the military sources of technologies that many people enjoy or feel required to use in everyday life. Yet, a deterministic approach to military "R\&D" can oversimplify the ways in which technoscience and its networks, including media and entertainment, produce hegemonic consent among the citizen/consumers of the present age.

Tim Lenoir has argued that changes in government procurement policies have prompted the military to "spin off" many of their key technologies during the last fifteen to twenty years. ${ }^{59}$ The case of GPS is more complicated, since it has been the property of the nonmilitary branches of the government through the Department of Transportation since the mid-1980s. Its partially declassified nature and unusually "open" practices while it was still under development made it particularly suitable for commercial "attention." By the early to mid-1990s, GPS had become ubiquitous in the United States, and its counterparts had become part of the orbital culture of other nations as well. The home page for "GPS World" (a typical site that promotes the technology) currently lists the following industry sectors as relevant to the technology: survey and construction, military and government, avionics and transportation, location-based services, agricultural and natural resources, utilities and communications, and systems design and testing. ${ }^{60}$ GPS is used in numerous leisure time pursuits from hunting to yachting, and it has even generated its own sports, such as geocaching (a game that utilizes GIS and GPS to hide "treasure" and log information) and "degree confluence" (a game in which participants compete to "visit" every latitude and longitude "integer degree intersection" in the world). GPS navigational aides can be found in watches, PDAs, phones, and other hand-held units as well as in most forms of transportation, both private and civil. In many ways, GPS has become a powerful metaphor and signifier for consumer culture at the turn of the century. ${ }^{61}$ And, of course, it is only more integrated into the warfare in Afghanistan and Iraq as another round of "democratization" is pursued by means of war in the Middle East and South Asia. ${ }^{62}$

If contemporary subjects of technoscience and its military-industrial-media-entertainment networks are constituted as targets, it is imperative that we understand this as a form of mobilization. Peter Miller and Nikolas Rose have argued that the subject of consumption is "mobilized" through the links between "human passions, hopes, and anxieties" and the "specific features of goods." ${ }^{63}$ I have tried to show how "precision" has entered the emotional 
field of subjectivity as the military-industrial complex has grown to encompass more fully the culture industries of media and entertainment. Thinking of consumer subjects as "mobilized" helps us in two regards. First, it allows us to move beyond the model of consumers as feminized, passive targets of unscrupulous advertisers in order to see the ways in which people participate in their construction by "volunteering," if you will, to engage in the products generated by technoscience. Secondly, it allows us to understand how citizens and consumers come together as militarized subjects through target marketing that seeks to identify their tastes, desires, and interests. The ambiguity of subject formation generates the complexities of political and cultural life in an affluent nation. Regardless of whether or not we serve in the military or have the means to afford the latest electronics, residents of the United States are mobilized into militarized ways of being.

The aftermath of the first Persian Gulf war, then, has witnessed not only another war in the same region but also a proliferation of GPS-enhanced consumer goods and civilian applications of the technology. This period has also seen a veritable explosion of data-mining and marketing based on geodemographics. ${ }^{64}$ Most recently, the method of identifying consumers by zip code has been challenged by more multileveled cross-referencing. For example, the "old" ACORN Market Segmentation System divided the country into more than 250,000 blocks of neighborhoods. Each block was analyzed and sorted by some forty-nine characteristics, including household income, occupation, age, education, age of the housing stock, and other characteristics of neighborhood purchasing power. Blocks were then recombined under forty-four market segments including, for example, "trendsetting, suburban neighborhoods," "older, depressed rural towns," and "Hispanic and multi-racial neighborhoods." 65 Throughout the 1990s there was mounting evidence of the growing importance of targeting consumers on the basis of "demography and habits rather than on the basis of geographical proximity"; as the maxim from 1980s advertising giant Saatchi \& Saatchi had it, there are greater differences between midtown Manhattan and the Bronx than between midtown Manhattan and the seventh arrondissement in Paris. ${ }^{66}$

At the turn of the century, then, it is possible to propose that the citizen/consumer subject in the United States is not so much identifiable in relation to intrinsic territories but mobilized as clusters of identities in and through consumption in the context of militarization. ${ }^{67}$ Militarization in the expanded sense in which I have been using it in this essay can be seen as a set of practices at work in sites of war, as well as those of consuming, schooling, worship, and homemaking. Yet, the deterritorializing tendencies of contem- 
porary geodemographics are tempered by the will to locate that subjects of consumption generate and require for identification. GIS- and GPS-linked technologies offer to tell citizen/consumers their precise location, positioning them geographically for any number of reasons. This recourse to terra firma can be seen as a recuperation of geography in the face of digitalized dispersal, but it can also be seen as an articulation of the world that GIS has wrought. The deep meaning of database culture in the age of the Internet is that the less we appear to need geographical information, the more it becomes clear how anchored contemporary power is to geography. That is, the anxiety over security, the call to militarize the borders of the nation, to further police the ports, to conduct satellite surveillance on individuals in their homes and places of work, shows us that the military-industrial-media-entertainment network reworks what geography means in terms of the nation-state under the sign of globalization and in the service of mobilization.

The ways in which the United States conducted war in the Persian Gulf in the early 1990s were made possible by the ways in which many U.S. residents became consumer and citizen subjects - through technoscience and its multiple, national, and transnational networks. Since that time, because power is scattered, unequal, and pervasive, war has become dispersed into many ways of being in the United States. ${ }^{68}$ Aiming for precision may be a symptom of that militarized dispersal of power, as fixity of location or identity resists the fluid dissolutions that are claimed to be a by-product of postmodernity. The marketing of location and navigation consumer goods both relies upon and generates discourses and practices of precision. In a time when nationalized empire employs the networks of technoscience and globalization to wage war on cultural, economic, and political fronts, it is necessary to analyze these circuits of power as serving nationalist interests, because the war can be ended only when we recognize our attachments to its subject-making potential.

Notes

I thank Donald Moore as well as Allan Pred, Jake Kosek, Bruce Braun, and Rebecca Stein for their warm encouragement at the very early stages of this project. Versions of this piece have been presented at UC Davis, Berkeley, and Santa Barbara; the American Studies Association; the American Anthropological Association; the International Conference in Critical Geography; and the "Seuils et Traverses III" conference. I have been greatly helped in my research and thinking about militarization and technology by Jennifer Terry's generous sharing of work in progress. Inderpal Grewal's work on security and consumer subjects continues to inspire me. Drafts at various stages have been read and commented upon most helpfully by Eric Smoodin, Minoo Moallem, Angela Harris, Greig Crysler, 
Carolyn de la Peña, and the anonymous readers for American Quarterly. I am extremely grateful to my research assistants at both UC Berkeley and UC Davis, most recently Mark Plotkin and Renée Vassilos, for their invaluable assistance.

1. Michel Foucault, "Truth and Power," in Power/Knowledge: Selected Interviews and Other Writings, 1972-1977, ed. Colin Gordon (New York: Pantheon, 1980), 114.

2. James Der Derian, Virtuous War: Mapping the Military-Industrial-Media-Entertainment Network (Boulder, Colo.: Westview, 2001); Tim Lenoir, "Programming Theatres of War: Gamemakers as Soldiers," in Bombs and Bandwidth: The Emerging Relationship Between Information Technology and Security, ed. Robert Latham (New York: New Press, 2003), 175-98; Jennifer Terry, Killer Entertainments: Conditions and Consequences of Remote Intimacy, work in progress.

3. Susan Mitchell, "Birds of a Feather," American Demographics, February 1995, http://www.marketingtools.com/Publications/AD/95_AD/9502_AD/9502AF03.htm (accessed May 26, 2006).

4. John Pickles, "Preface," Ground Truth: The Social Implications of Geographic Information Systems, ed. John Pickles (New York: Guilford, 1995), viii.

5. N.A., "Geographic information system," http://en.wikipedia.org/wiki/Geographic_information_system (accessed May 14, 2006).

6. See Denis Cosgrove, Apollo's Eye: A Cartographic Genealogy of the Earth in the Western Imagination (Baltimore: Johns Hopkins University Press, 2001); and Susan M. Roberts and Richard H. Schein, "Earth Shattering: Global Imagery and GIS," in Ground Truth, ed. Pickles, 171-95.

7. Development of GPS was begun by the U.S. Air Force in 1960. In 1974 the Department of Defense launched the first of twenty-four satellites as the NAVSTAR system.

8. GPS operates through the triangulation of radio signals, fixing position in three dimensions: latitude, longitude, and altitude. Atomic clocks synchronize GPS time, allowing for an unprecedented level of precision in fixing position.

9. Paul Virilio, War and Cinema: The Logistics of Perception (London: Verso, 1989).

10. Mark Lewyn, "Where Am I? Ask a Satellite," Business Week, October 26, 1992, 116.

11. L. Casey Larijani, GPS for Everyone: How the Global Positioning System Can Work for You (New York: American Interface Corporation, 1998), 1-2.

12. Gregory T. French, Understanding the GPS: An Introduction to the Global Positioning System (Bethesda, Md.: GeoResearch, 1996), 5.

13. Ibid., 3 .

14. Doug Abberley, "The Lure of Mapping: An Introduction," in Boundaries of Home: Mapping for Local Empowerment (Philadelphia: New Society, 1993), 1.

15. Navigation and positioning are not the same thing. But most navigation proceeds from a standard of location or reckoning of distance between established locations. Thus, most navigation technologies rely on accurate determinations of positions.

16. Michael Pearce, "An Answer to the Age-Old Cry: Where on Earth Am I?" The Wall Street Journal, March 24, 1994, A12.

17. Frank Vizard, "Lost in America-Not!” Rolling Stone, May 28, 1992, 67.

18. Steve Ditlea, "Real Men Don't Ask Directions," Popular Science, March 1995, 86-89, 120-21.

19. Jeff Bertolucci, "Find Yourself with GPS MapKit SV,” PC World, July 1993, 84.

20. For recent discussions of "targets" in the humanities and area studies as well as urban studies, see Samuel Weber, Targets of Opportunity: On the Militarization of Thinking (New York: Fordham University Press, 2005); Rey Chow, The Age of the World Target: Self-Referentiality in War, Theory, and Comparative Work (Durham, N.C.: Duke University Press, 2006); and Ryan Bishop, Gregory Clancy, and John Phillips, "Just Targets," Cultural Politics 2.1 (March 2006): 5-28.

21. See Norman J. W. Thrower, Maps and Civilization: Cartography in Culture and Society (Chicago: Chicago University Press, 1996); J. B. Harley, The New Nature of Maps: Essays in the History of Cartography (Baltimore: Johns Hopkins University Press, 2001); David Turnbull, Maps Are Territories: Science Is an Atlas (Chicago: University of Chicago Press, 1989); Walter D. Mignolo, Local Histories/Global Designs: Coloniality, Subaltern Knowledges, and Border Thinking (Princeton, N.J.: Princeton University Press, 2000); and Matthew Sparke, "Mapped Bodies and Disembodied Maps: (Dis)placing Cartographic Struggle in Colonial Canada," in Places through the Body, ed. Heidi J. Nast and Steve Pile (New York: Routledge, 1998), 305-36.

22. See Virilio, War and Cinema; Beaumont Newhall, Airborne Camera: The World from the Air and Outer Space (New York: Hastings House, 1969); Caren Kaplan, "Mobility and War: The Cosmic View of U.S. 
'Air Power," Environment and Planning A 38.2 (February 2006): 395-407; Anthony Vidler, "Terres Inconnues: Cartographies of a Landscape to be Invented,” October 115 (Winter 2006): 13-30; Linda Robertson, The Dream of Civilized Warfare: World War I Flying Aces and the American Imagination (Minneapolis: University of Minnesota Press, 2003); K. B. Atkinson, ed., Close Range Photogrammetry and Machine Vision (Caithness, Scotland: Whittles, 1996); David Buisseret, ed., From Sea Charts to Satellite Images: Interpreting North American History through Maps (Chicago: University of Chicago Press, 1990).

23. Albert L. Pardini, The Legendary Norden Bombsight (Atglen, Pa.: Schiffer Military History, 1999), 16.

24. I am grateful to one of the anonymous reviewers for this excellent point.

25. Donald MacKenzie, Inventing Accuracy: A Historical Sociology of Nuclear Missile Guidance (Cambridge, Mass.: MIT Press, 1990), 3.

26. "In the penultimate draft of the address, Eisenhower initially used the term military-industrial-congressional complex, indicating the essential role that the U.S. Congress plays in propagating the military industry. But, it is said that the president chose to strike the word congressional in order to avoid offending members of the legislative branch of the federal government." See http://en.wikipedia. org/wiki/Military_industrial_complex (accessed June 1, 2006).

27. Conrad C. Crane, Bombs, Cities, and Civilians: American Airpower Strategy in World War II (Lawrence: University Press of Kansas, 1993); and Williamson Murray, War in the Air: 1914-45 (London: Cassell, 1999).

28. Crane, Bombs, Cities, and Civilians, 19.

29. Murray, War in the Air, 31.

30. Stephen McFarland, America's Pursuit of Precision Bombing, 1910-1945 (Washington, D.C.: Smithsonian Books, 1995).

31. Ibid., 5 .

32. Crane, Bombs, Cities, and Civilians, 20.

33. Pardini, The Legendary Norden Bombsight, 16.

34. See for example, autobiographical accounts such as this one at http://www.486th.org/Assn/NL/NL0202. htm\#sight (accessed February 24, 2006).

35. Crane, Bombs, Cities, and Civilians, 64.

36. Murray, War in the Air, 96.

37. Sven Lindqvist, A History of Bombing (New York: New Press, 2000)

38. Alastair Finlan, The Gulf War 1991 (Oxford: Osprey, 2003), 86-87.

39. See Matthew Mowthorpe, The Militarization and Weaponization of Space (Oxford: Lexington Books, 2004); and Paul B. Stares, The Militarization of Space: U.S. Policy, 1945-1984 (Ithaca, N.Y.: Cornell University Press, 1985).

40. Richard Alan Schwartz, Encyclopedia of the Persian Gulf War (Jefferson: McFarland, 1998), 171.

41. "The big difference was that for the first time ever, we had the first television war that was live ... Vietnam was a film war." David Schmerler, NBC news, quoted by Linda Jo Calloway, "High Tech Comes to War Coverage: Uses of Information and Communications Technology for Television Coverage in the Gulf War," in The 1,000 Hour War: Communication in the Gulf, ed. Thomas A. McCain and Leonard Shyles (Westport, Conn.: Greenwood, 1994), 65.

42. Ibid., 57.

43. Robert Stam, "Mobilizing Fictions: The Gulf War, the Media, and the Recruitment of the Spectator," Public Culture 4.2 (Spring 1992): 101-23.

44. See John Taylor, War Photography: Realism in the British Press (New York: Routledge, 1991).

45. Stig A. Nohrstedt, "Ruling by Pooling," in Triumph of the Image: The Media's War in the Persian Gulf-A Global Perspective, ed. Hamid Mowlana et al. (Boulder, Colo.: Westview, 1992), 119.

46. Douglas Kellner, The Persian GulfTVWar (Boulder, Colo.: Westview, 1992), 139.

47. Journalist John Fialka remembers, "We were escorted away from most of the violence because the bodies of the dead, chopped up by artillery, pulverized by B-52 raids, or lacerated by friendly fire, don't play well, politically.” John J. Fialka, Hotel Warriors: Covering the Gulf War (Baltimore: Johns Hopkins University Press, 1992), 2.

48. There is an extensive literature on the media and visual politics and practices of the first Persian Gulf War. In addition to works cited elsewhere in this text, and without providing a full bibliography here, the following works have been helpful to me: Judith Butler, "The Imperialist Subject," The Journal of 
Urban and Cultural Studies 2.1 (1991): 73-78; Victor J. Caldarola, "Time and the Television War," Public Culture 4.2 (Spring 1994); Susan Jeffords and Lauren Rabinovitz, eds., Seeing through the Media: The Persian Gulf War (New Brunswick, N.J.: Rutgers, 1994); Marita Sturken, Tangled Memories: The Vietnam War, the AIDS Epidemic, and the Politics of Remembering (Berkeley: University of California Press, 1997); Ian Walker, "Desert Stories or Faith in Facts?" in The Photographic Image in Digital Culture, ed. Martin Lister (New York: Routledge, 1995), 236-52; Georges van den Abbeele, "Lethal Mobilities: Calvin and the Smart Bomb," Annali d'talianistica 21 (2003): 363-78; Elaine Scarry, "Watching and Authorizing the Gulf War," in Media Spectacles, ed. Marjorie Garber et al. (New York: Routledge, 1993), 57-73; and Danny Schechter, "The Gulf War and the Death of TV News," The Independent, January/February 1992, 28-31.

49. Daniel C. Hallin, "Images of Vietnam and the Persian Gulf Wars in U.S. Television," in Jeffords and Rabinovitz, Seeing through the Media, 56.

50. Ibid.

51. Editorial, Nation, February 11, 1991, 147, cited in Farrel Corcoran, "War Reporting: Collateral Damage in the European Theater," in Mowlana et al., 109.

52. Fred Kaplan, "U.S. Bombs Not That Much Smarter," Boston Globe, February 20, 1998, A1.

53. M. David Arant and Michael L. Warden, "The Military and the Media: A Clash of Views on the Role of the Press in Time of War," in McCain and Shyles, The 1,000 Hour War, 36.

54. Middle East Watch, Needless Deaths in the Gulf War: Civilian Casualties during the Air Campaign and Violations of the Laws of War (New York: Human Rights Watch, 1991), 19.

55. Inderpal Grewal, Transnational America: Feminisms, Diasporas, Neoliberalisms (Durham, N.C.: Duke University Press, 2005), 219-20.

56. Donna J. Haraway, Modest_Witness@Second_Millennium.FemaleMan $@ \_$Meets_OncoMouse TM: Feminism and Technoscience (New York: Routledge, 1996), 51.

57. Jordan Crandall, "Operational Media," www.ctheory.net/articles.aspx?d=441, article a148 (accessed January 18,2006$)$.

58. Ibid. See also N. Katherine Hayles, How We Became PostHuman: Virtual Bodies in Cybernetics, Literature, and Informatics (Chicago: University of Chicago Press, 1999); Paul N. Edwards, The Closed World: Computers and the Politics of Discourse in Cold War America (Cambridge, Mass.: MIT Press, 1999); Lev Manovich, The Language of New Media (Cambridge, Mass.: MIT Press, 2001); Manuel DeLanda, "Ecologies, Representations, and the Affective Dimension of Image Reception," in Under Fire 1: The Organization and Representation of Violence, ed. Jordan Crandall (Rotterdam: Witte De With, Center for Contemporary Art, 2004).

59. Lenoir, "Programming Theatres of War."

60. See http://www.gpsworld.com/gpsworld/.

61. See Carolyn de la Peña, "Ready-to-Wear Globalism: Mediating Materials and Prada’s GPS," Winterthur Portfolio 38.2-3 (Summer-Autumn 2003): 100-129.

62. Some of the problems that were encountered during the first Persian Gulf War have been purported to be solved by the next generation of GPS guided weapons such as JDAM (Joint Direct Attack Munition) and JSOW (Joint Stand-Off Weapon). Global Security lists 22 bombs guided by GPS in use by the U.S. military in the present conflicts. According to the same site, since the first Persian Gulf War, the Air Force has tripled the number of precision weapons and enhanced accuracy (http://www. globalsecurity.org/military/systems/munitions/smart.htm). However, the "precision" of the strikes in the recent conflicts continues to be debated. Continuing his long-standing attention to the issue of civilian deaths from precision guided weapons, Fred Kaplan reported in 2003 that the accuracy rate of the GPS in use in Iraq remains approximately 10-100 meters and that this combined with any inaccuracy in intelligence results in less than "pinpoint" attacks-with numerous civilians killed in the effort to "hit" high-profile leadership in the opposition. Yet the purported accuracy of the weapons systems encourages the attempt to assassinate individuals via long-range missile strike. Fred Kaplan, "Smart Bombs, Dumb Targets," http://www.slate.com/id/2092759/. (accessed May 10, 2006).

63. Peter Miller and Nikolas Rose, "Mobilizing the Consumer: Assembling the Subject of Consumption," Theory, Culture, \& Society 14.1 (February 1997): 2.

64. See David J. Grimshaw, Bringing Geographical Information Systems into Business (New York: John Wiley, 2000); Richard Harris et al., Geodemographics, GIS, and Neighborhood Targeting (New York: John Wiley, 2005); and Irvine Clarke III and Theresa B. Flaherty, Advances in Electronic Marketing (Hershey, Pa.: Idea Group, 2005). 
65. Donald Lowe, The Body in Late-Capitalist USA (Durham, N.C.: Duke University Press, 1996), 64-66.

66. Kevin Robins, "Tradition and Translation: National Culture in Its Global Context," in Enterprise and Heritage, ed. John Corner and Sylvia Harvey (New York: Routledge, 1991), 27.

67. See Mark Poster, "Databases as Discourse; or, Electronic Interpellations," in Computers, Surveillance, and Privacy, ed. David Lyon and Elia Zureik (Minneapolis: University of Minnesota Press, 1996), $175-92$.

68. See Inderpal Grewal and Caren Kaplan, "Introduction: Transnational Feminist Practices and Questions of Postmodernity," in Scattered Hegemonies: Postmodernity and Transnational Feminist Practices (Minneapolis: University of Minnesota Press, 1994), 1-36. 